\title{
Hydrogenobacter acidophilus sp. nov., a Thermoacidophilic, Aerobic, Hydrogen-Oxidizing Bacterium Requiring Elemental Sulfur for Growth
}

\author{
SEIGO SHIMA ${ }^{2 *}$ AND KEN-ICHIRO SUZUKI ${ }^{2}$ \\ Department of Biology, Abiko Research Laboratory, Central Research Institute of Electric Power Industry, \\ 1646 Abiko, Abiko-City, Chiba 270-11, ${ }^{1}$ and Japan Collection of Microorganisms, The Institute of \\ Physical and Chemical Research (RIKEN), Wako-shi, Saitama 351-01, ${ }^{2}$ Japan
}

\begin{abstract}
A thermoacidophilic, obligately chemolithoautotrophic, aerobic, hydrogen-oxidizing bacterium, strain 3H-1 ${ }^{\mathrm{T}}$ ( $\mathrm{T}=$ type strain), was isolated from a solfataric field in Tsumagoi, Japan. This strain is a gram-negative, motile, non-spore-forming rod-shaped organism that requires elemental sulfur for growth by hydrogen oxidation. Type $b, c$, and $o$ cytochromes are present. Carbon dioxide may be fixed via the reductive tricarboxylic acid cycle. The optimum temperature for growth is $65^{\circ} \mathrm{C}$. The optimum pH for growth is 3.0 to 4.0. The guanine-plus-cytosine content of DNA is 35.0 mol\%. A straight-chain saturated $C_{18: 0}$ acid and straight-chain unsaturated $C_{18: 1}$ and $C_{20: 1}$ acids are the major components of the cellular fatty acids. 2-Methylthio-3-VI,VII-tetrahydromultiprenyl ${ }^{7}$-1,4-naphthoquinone (methionaquinone) is the major isoprenoid quinone. This strain is considered a member of a new species of the genus Hydrogenobacter, a genus of obligately chemolithoautotrophic, aerobic, hydrogen-oxidizing bacteria. The name Hydrogenobacter acidophilus sp. nov. is proposed for the organism. The type strain of this species is strain 3H-1 (= JCM 8795).
\end{abstract}

Hydrogenobacter thermophilus was the first reported obligate chemolithoautotroph among the aerobic hydrogenoxidizing bacteria. Strains of this species were isolated from hot springs in Japan by Kawasumi et al. $(10,11)$, and subsequently several obligately chemolithoautotrophic, aerobic, hydrogen-oxidizing bacteria similar to $H$. thermophilus were isolated from other hot springs $(16,17)$. A halophilic strain ("Hydrogenobacter halophilus") was isolated from a seaside saline hot spring (20).

Many thermoacidophiles have been isolated from solfataric fields which contain hydrogen gas and reduced sulfur compounds $(25,26)$. Several organisms that live in solfataric fields utilize hydrogen or reduced sulfur compounds as energy sources. Members of the genera Sulfolobus and Thermoplasma are aerobic archaea that grow chemolithoautotrophically by oxidizing reduced sulfur compounds. Members of the genus Acidianus grow not only by aerobically oxidizing reduced sulfur compounds, but also by anaerobically reducing elemental sulfur, using hydrogen (26).

All of the Hydrogenobacter strains described previously were isolated from hot springs and were neutrophilic (1). Previously no Hydrogenobacter strain has been isolated from an acidic solfatara. Bacillus tusciae is the only hydrogen-oxidizing bacterium that has been isolated from acidic ponds at a solfataric field $(1,3)$. However, $B$. tusciae is a facultative autotroph and moderate thermoacidophile.

In this paper we describe the isolation and characterization of a thermoacidophilic, obligately chemolithoautotrophic, aerobic, hydrogen-oxidizing bacterium that requires elemental sulfur for growth. This organism is described as a new species, Hydrogenobacter acidophilus.

\section{MATERIALS AND METHODS}

Bacterial strains. The bacteria used for reference in DNADNA hybridization and chemical component analyses were

\footnotetext{
* Corresponding author.
}

Calderobacterium hydrogenophilum JCM $8158^{\mathrm{T}}$ (= DSM $2913^{\mathrm{T}}=$ N. D. Savelyeva Z-829 $)(\mathrm{T}=$ type strain) $(17) . H$. thermophilus JCM $7687^{\mathrm{T}}\left(=\right.$ T. Kodama TK-6 $\left.{ }^{\mathrm{T}}\right)$ and TK-G (11), and "H. halophilus" JCM 7551 (= T. Kodama TH112) (20).

Medium. The medium used for isolation and cultivation contained (per liter) $5.0 \mathrm{~g}$ of elemental sulfur, $1.0 \mathrm{~g}$ of $\left(\mathrm{NH}_{4}\right)_{2} \mathrm{SO}_{4}, 1.0 \mathrm{~g}$ of $\mathrm{K}_{2} \mathrm{HPO}_{4}, 1.0 \mathrm{~g}$ of $\mathrm{NaCl}, 0.3 \mathrm{~g}$ of $\mathrm{MgSO}_{4} \cdot 7 \mathrm{H}_{2} \mathrm{O}, 1.0 \mathrm{mg}$ of $\mathrm{FeSO}_{4} \cdot 7 \mathrm{H}_{2} \mathrm{O}, 1.0 \mathrm{mg}$ of $\mathrm{CaCl}_{2}$, $0.06 \mathrm{mg}$ of $\mathrm{NiSO}_{4} \cdot 6 \mathrm{H}_{2} \mathrm{O}$, and $2.0 \mathrm{ml}$ of a trace elements solution; the $\mathrm{pH}$ was adjusted to 3.0 with $\mathrm{HCl}$. The trace elements solution contained (per liter) $1.0 \mathrm{mg}$ of $\mathrm{MoO}_{3}, 7.0$ $\mathrm{mg}$ of $\mathrm{ZnSO}_{4} \cdot 7 \mathrm{H}_{2} \mathrm{O}, 0.5 \mathrm{mg}$ of $\mathrm{CuSO}_{4} \cdot 5 \mathrm{H}_{2} \mathrm{O}, 1.0 \mathrm{mg}$ of $\mathrm{H}_{3} \mathrm{BO}_{3}, 1.0 \mathrm{mg}$ of $\mathrm{MnSO}_{4} \cdot 5 \mathrm{H}_{2} \mathrm{O}$, and $1.0 \mathrm{mg}$ of $\mathrm{CoCl}_{2}$. $6 \mathrm{H}_{2} \mathrm{O}(10)$. For a solid medium, $1.0 \%$ Gellan gum (Wako Pure Chemical Industry, Ltd., Osaka, Japan) was added to the medium described above without elemental sulfur. Plates were prepared by overlaying the solid medium with colloidal sulfur prepared as described by Kurtennacker (18).

Isolation procedure. Enrichment cultures were prepared in test tubes ( 18 by $180 \mathrm{~mm}$ ) containing $5 \mathrm{ml}$ of medium. The test tubes were sealed with butyl rubber stoppers. Samples (acidic mud samples from solfataras) collected at Tsumagoi, Gunma, Japan, were inoculated. The test tubes were gassed with a gas mixture $\left(\mathrm{H}_{2}-\mathrm{O}_{2}-\mathrm{CO}_{2}, 8: 1: 1 ; 1 \mathrm{~atm}\right.$ [101.29 kPa]) and shaken with a reciprocating shaker at 140 oscillations per min at $60^{\circ} \mathrm{C}$ for 3 days. After growth had occurred, $0.5 \mathrm{ml}$ of each culture was transferred to $5 \mathrm{ml}$ of fresh medium and the preparations were incubated for 2 days. After this procedure was repeated, sequential serial dilutions were carried out twice. The culture was purified by single-colony isolation on plate medium under a gas phase $\left(\mathrm{H}_{2}-\mathrm{O}_{2}-\mathrm{CO}_{2}\right.$, 8.5:0.5:1; 1 atm [101.29 $\mathrm{kPa}])$.

Cultivation. The culture conditions used for cell harvesting and the growth tests described below were the same as the conditions used for the enrichment culture described above, unless otherwise specified. Because the numbers of living cells in cultures of the isolate decreased rapidly in the stationary phase, log-phase cells were used as an inoculum. 
For large-scale cultivation, a 2.6-liter fermentor containing 1.5 liters of medium in which the $\mathrm{pH}$ was maintained at $\mathrm{pH}$ 3.0 was used. To determine the optimum $\mathrm{pH}$, cultures were grown in the fermentor. Cell concentrations were determined by measuring turbidity at $600 \mathrm{~nm}$ with a spectrophotometer and by counting cells with a counting chamber. To determine production of $\mathrm{SO}_{4}{ }^{2-}, 10$-fold-diluted medium was used to decrease the background $\mathrm{SO}_{4}{ }^{2-}$ concentration.

Utilization of inorganic energy sources. $\mathrm{Na}_{2} \mathrm{~S}_{2} \mathrm{O}_{3}(20 \mathrm{mM})$, $\mathrm{K}_{2} \mathrm{~S}_{4} \mathrm{O}_{6}(10 \mathrm{mM}), \mathrm{Na}_{2} \mathrm{SO}_{3}(1$ and $10 \mathrm{mM}), \mathrm{NaSCN}(1$ and 10 $\mathrm{mM}), \mathrm{FeSO}_{4}(5 \mathrm{mM})$, and $\mathrm{MnCl}_{2}(1 \mathrm{mM})$ were added to the medium in place of elemental sulfur to determine the possible utilization of these compounds as sources of energy. The cultures were incubated with various gas mixtures and were either shaken or kept stationary.

Assimilation of organic compounds. Cultures were incubated under air for more than 10 days on organic media containing the following substances: acetate, $n$-butyrate, citrate, formate, fumarate, gluconate, glycolate, lactate, maleate, DL-malate, propionate, pyruvate, succinate, D-fructose, galactose, glucose, glycerol, lactose, maltose, D-mannitol, D-mannose, melibiose, raffinose, L-rhamnose, D-ribose, D-sorbitol, sucrose, D-xylose, soluble starch, ethanol, methanol, 20 different L-amino acids, brain heart infusion (Difco Laboratories, Detroit, Mich.), beef extract (Difco), Casamino Acids (Difco), Bacto Peptone (Difco), tryptone (Difco), yeast extract (Difco), and nutrient broth (Difco). Each organic compound except formate was added to the medium (without elemental sulfur) at a concentration of $0.1 \%(\mathrm{wt} / \mathrm{vol})$. Growth on formate was investigated in detail by using various concentrations $(100,50,20,10$, and $5 \mathrm{mM})$. Because of the possibility that the isolate could be an oligotrophic bacterium, growth was tested on 100-fold-diluted brain heart infusion medium, nutrient broth, and yeast extract-peptone-glucose medium $(10 \mathrm{mg}$ of yeast extract per liter, $20 \mathrm{mg}$ of peptone per liter, $5 \mathrm{mg}$ of glucose per liter).

Enzyme activities. Late-logarithmic-phase cells were harvested, suspended in $50 \mathrm{mM}$ phosphate buffer ( $\mathrm{pH} 7.0$ ), and broken by passing them twice through a French pressure cell at $12,000 \mathrm{~kg} / \mathrm{cm}^{2}$. A cell extract was prepared by centrifuging the preparation at $28,000 \times g$ for $20 \mathrm{~min}$ at $4^{\circ} \mathrm{C}$ to remove unbroken cells. The resulting cell extract was centrifuged at $145,000 \times g$ for $1 \mathrm{~h}$ at $4^{\circ} \mathrm{C}$. The supernatant was used as a soluble fraction, and the pellet was suspended in $50 \mathrm{mM}$ phosphate buffer ( $\mathrm{pH} 7.0$ ) and used as a membrane fraction for the detection of hydrogenase activity. Hydrogenase activity was assayed spectrophotometrically by measuring methylene blue reduction and NAD reduction at $60^{\circ} \mathrm{C}$ as described by Knüttel et al. (13). The ribulose-1,5-bisphosphate carboxylase activity of the cell extract was measured radiometrically at $65^{\circ} \mathrm{C}$ as described by Nishihara et al. (19). The ATP:citrate lyase activity of the cell extract was determined spectrophotometrically at $60^{\circ} \mathrm{C}$ by the method of Takeda et al. (29). Cytochrome $c$ oxidase and malate dehydrogenase activities were assayed by the methods of Storrie and Madden (27) and Kitto (12), respectively.

Cytochrome systems. The cell extract described above was subjected to spectrophotometry to test for the presence of cytochrome systems as described by Beatrice and Chappell (2).

Chemotaxonomic characteristics. The isoprenoid quinone and cellular fatty acid compositions of isolates were determined as described by Komagata and Suzuki (14). Latelogarithmic-phase cells were harvested and lyophilized. The quinones were purified by thin-layer chromatography and analyzed by high-performance liquid chromatography
(HPLC) and mass spectrometry. Fatty acid methyl esters were prepared with methanolic $\mathrm{HCl}$ and were analyzed by using a gas chromatograph equipped with a capillary column coated with OV-1.

DNA was isolated by the method of Saito and Miura (22), with minor modifications. The base composition of DNA was determined by reversed-phase HPLC as described by Tamaoka and Komagata (30). The membrane filter method was used to determine DNA-DNA reassociation values (28). Hybridization was performed at $60^{\circ} \mathrm{C}$ for $36 \mathrm{~h}$ in $2 \times \mathrm{SSC}(1 \times$ SSC is $0.15 \mathrm{M} \mathrm{NaCl}$ plus $15 \mathrm{mM}$ trisodium citrate, $\mathrm{pH} 7.0$ ) containing $0.1 \%$ sodium dodecyl sulfate.

\section{RESULTS}

Isolation. Two strains, $3 \mathrm{H}-1^{\mathrm{T}}$ and $3 \mathrm{H}-3$, were obtained in the course of isolation from solfatara mud samples ( $\mathrm{pH} 2$ to $3,30^{\circ} \mathrm{C}$ ). Strain $3 \mathrm{H}-1^{\mathrm{T}}$ formed smooth reddish brown colonies on the solid medium. The colonies grew to a diameter of approximately $0.6 \mathrm{~mm}$ after 3 days of incubation. Strain $3 \mathrm{H}-3$ had properties similar to those of strain $3 \mathrm{H}-1^{\mathrm{T}}$, which was used in most of the studies described below.

Phenotypic and cultural characteristics. Strain $3 \mathrm{H}-1^{\mathrm{T}}$ was a gram-negative short, rod-shaped organism 1.3 to $1.8 \mu \mathrm{m}$ long and 0.4 to $0.6 \mu \mathrm{m}$ in diameter. It occurred singly or as a linked chain of two to four cells, and each cell was motile by means of a polar flagellum (Fig. 1). Spore formation was not observed.

Strain $3 \mathrm{H}-1^{\mathrm{T}}$ grew optimally at $\mathrm{pH} 3.0$ to 4.0 , and slight growth occurred at pH 2.0 and 6.0 (Fig. 2A). The highest growth rate was observed at about $65^{\circ} \mathrm{C}$, and no growth occurred at 40 or $75^{\circ} \mathrm{C}$ (Fig. 2B). Strain $3 \mathrm{H}-1^{\mathrm{T}}$ was aerobic but did not grow at a partial $\mathrm{O}_{2}$ pressure $\left(\mathrm{pO}_{2}\right)$ of $30 \%$. No growth was observed under anaerobic conditions reduced by $\mathrm{Na}_{2} \mathrm{~S}(0.75 \mathrm{~g} /$ liter $)$. The optimum $\mathrm{pO}_{2}$ was between 2 and $10 \%$, and no lag time was observed at $\mathrm{pO}_{2} \mathrm{~s}$ of $2,5,10$, and $20 \%$. Strain $3 \mathrm{H}-1^{\mathrm{T}}$ grew under optimum growth conditions with a specific growth rate of approximately $0.6 \mathrm{~h}^{-1}$.

Utilization of inorganic energy sources. Strain $3 \mathrm{H}-1^{\mathrm{T}}$ exhibited good growth with hydrogen in the presence of elemental sulfur. However, it did not grow on hydrogen without elemental sulfur. Thiosulfate had the same effect as elemental sulfur. However, elemental sulfur was produced chemically from thiosulfate under acidic conditions. Thus, it is not known whether strain $3 \mathrm{H}-1^{\mathrm{T}}$ utilized thiosulfate under these conditions. Strain $3 \mathrm{H}-1^{\mathrm{T}}$ grew slowly with elemental sulfur and thiosulfate in the absence of hydrogen. Decreases in $\mathrm{pH}$ and production of $\mathrm{SO}_{4}{ }^{2-}$ were observed when the organism was cultivated with elemental sulfur and thiosulfate in the presence and absence of hydrogen. Tetrathionate, sulfite, thiocyanate, $\mathrm{Fe}^{2+}, \mathrm{Mn}^{2+}$, ammonium, and nitrite ions were not utilized as sole energy sources. Hydrogen was not utilized by strain $3 \mathrm{H}-1^{\mathrm{T}}$ unless elemental sulfur or thiosulfate was present in the medium.

Assimilation of organic compounds. Strain $3 \mathrm{H}-1^{\mathrm{T}}$ did not grow heterotrophically on any organic medium tested. This suggests that strain $3 \mathrm{H}-1^{\mathrm{T}}$ is an obligate chemolithoautotroph.

$\mathrm{CO}_{2}$-fixing pathway. Activity of ATP:citrate lyase, the key enzyme of the reductive tricarboxylic acid cycle, in cell extracts of strain $3 \mathrm{H}-1^{\mathrm{T}}$ was detected and was not less than the activity in the type strain of $H$. thermophilus (7). In contrast, activity of ribulose-1,5-bisphosphate carboxylase, the key enzyme of the reductive pentose phosphate cycle (the Calvin cycle), was not detected, suggesting that strain $3 \mathrm{H}-1^{\mathrm{T}}$ fixes $\mathrm{CO}_{2}$ via the reductive tricarboxylic acid cycle. 


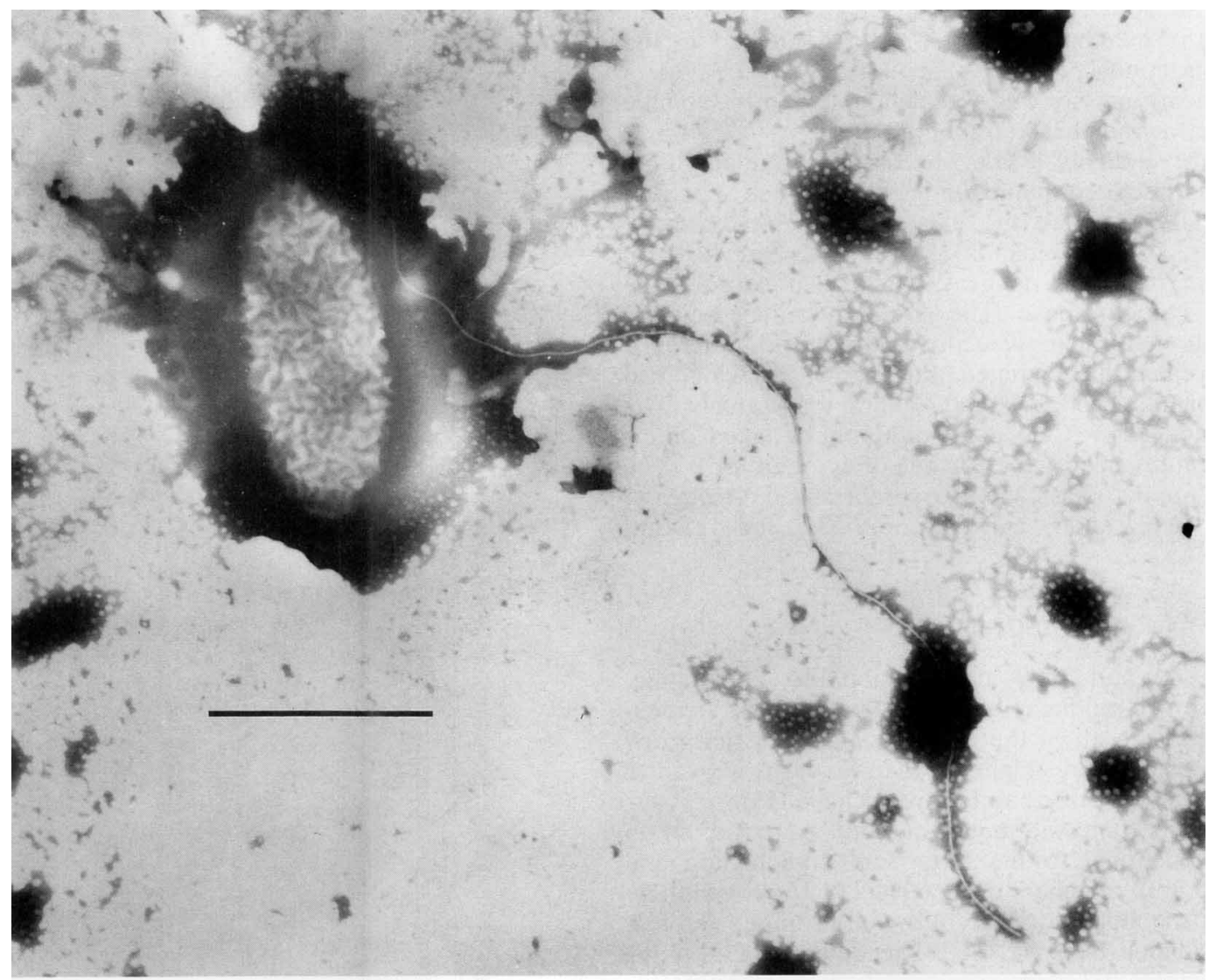

FIG. 1. Electron micrograph of negatively stained strain $3 \mathrm{H}-1^{\mathrm{T}}$. Bar $=1 \mu \mathrm{m}$.

Chemotaxonomic characteristics. The quinone of strain $3 \mathrm{H}-1^{\mathrm{T}}$ produced a single peak on an HPLC chromatogram. The mass spectrum was identical to that of $H$. thermophilus (9). Thus, the isoprenoid quinone of strain $3 \mathrm{H}-1^{\mathrm{T}}$ appears to be 2-methylthio-3-VI, VII-tetrahydromultiprenyl ${ }^{7}$-1,4-naphthoquinone (methionaquinone).
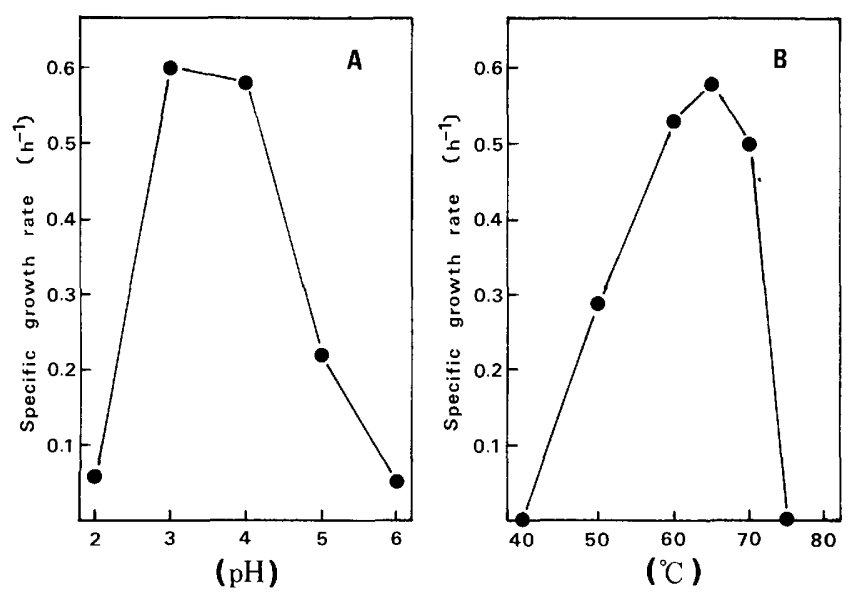

FIG. 2. Effects of pH (A) and temperature (B) on autotrophic growth of strain $3 \mathrm{H}-1^{\mathrm{T}}$ by hydrogen oxidation. Cultures were grown in isolation medium containing elemental sulfur with an $\mathrm{H}_{2}-\mathrm{O}_{2}-\mathrm{CO}_{2}$ (8:1:1) gas phase on a reciprocating shaker.
The predominant cellular fatty acids of strain $3 \mathrm{H}-1^{\mathrm{T}}$ were $\mathrm{C}_{18: 0}$ acid $(17.9 \%), \mathrm{C}_{18: 1}$ acid $(18.4 \%)$, and $\mathrm{C}_{20: 1}$ acid $(56.1 \%)$.

The DNA base composition of strain $3 \mathrm{H}-1^{\mathrm{T}}$ was determined to be $35.0 \mathrm{~mol} \% \mathrm{G}+\mathrm{C}$ by HPLC.

No significant level of DNA-DNA homology was detected between strain $3 \mathrm{H}-1^{\mathrm{T}}$ and the Hydrogenobacter and Calderobacterium strains tested (Table 1).

Distribution of hydrogenase. Methylene blue reducing activity was distributed in both the soluble (42\%) and membrane $(30 \%)$ fractions. In this study, $94 \%$ of the activity of malate dehydrogenase, a marker of cytoplasmic enzymes,

TABLE 1. Levels of reassociation between strain $3 \mathrm{H}-1^{\mathbf{T}}$, Hydrogenobacter, and Calderobacterium DNAs

\begin{tabular}{|c|c|c|c|c|}
\hline \multirow{2}{*}{$\begin{array}{l}\text { Filter-bound DNA } \\
\text { from: }\end{array}$} & \multicolumn{4}{|c|}{$\%$ Reassociation with ${ }^{3} \mathrm{H}$-labelled DNA from: } \\
\hline & $\begin{array}{l}\text { Strain } \\
3 \mathrm{H}-1^{\mathrm{T}}\end{array}$ & $\begin{array}{c}\text { Strain } \\
\text { JCM } 7687^{\mathrm{T}}\end{array}$ & $\begin{array}{c}\text { Strain } \\
\text { JCM } 7551\end{array}$ & $\begin{array}{l}\text { Strain JCM } \\
8185^{\mathrm{T}}\end{array}$ \\
\hline Strain $3 \mathrm{H}-1^{\mathrm{T}}$ & 100 & 2 & 2 & 3 \\
\hline $\begin{array}{l}\text { H. thermophilus } \\
\text { JCM } 7687^{\mathrm{T}}\end{array}$ & 1 & 100 & 4 & 18 \\
\hline $\begin{array}{l}\text { H. thermophilus } \\
\text { TK-G }\end{array}$ & 1 & 84 & 4 & 17 \\
\hline $\begin{array}{c}\text { "H. halophilus" } \\
\text { JCM } 7551\end{array}$ & 1 & 3 & 100 & 3 \\
\hline $\begin{array}{l}\text { C. hydrogenophilum } \\
\text { JCM } 8158^{\mathrm{T}}\end{array}$ & 1 & 10 & 2 & 100 \\
\hline
\end{tabular}


and $72 \%$ of the activity of cytochrome $c$ oxidase, a marker enzyme of the membrane fraction, were detected in the appropriate fractions.

NAD-reducing activity was detected in neither the soluble fractions nor the membrane fractions.

Cytochrome systems. The ascorbate-tetramethylphenylenediamine reduced-minus-oxidized difference spectrum of strain $3 \mathrm{H}-1^{\mathrm{T}}$ revealed the existence of cytochrome $c$ which had $\alpha, \beta$, and $\gamma$ bands at 551, 521, and $417 \mathrm{~nm}$, respectively. There was no peak which demonstrated the existence of cytochrome $a$. The dithionite-reduced-minusascorbate-tetramethylphenylenediamine-reduced difference spectrum revealed the existence of cytochrome $b$ which had $\alpha, \beta$, and $\gamma$ bands at 560,530 , and $430 \mathrm{~nm}$, respectively. The (dithionite-reduced $+\mathrm{CO}$ )-minus-dithionite-reduced difference spectrum revealed the existence of cytochrome $o$. The spectrum of the cytochrome $o$-CO complex had a trough at $552 \mathrm{~nm}$ and $\alpha, \beta$, and $\gamma$ bands at 562,537 , and $415 \mathrm{~nm}$, respectively.

\section{DISCUSSION}

Strains $3 \mathrm{H}-\mathbf{1}^{\mathrm{T}}$ and $3 \mathrm{H}-3$ are thermophilic, acidophilic, aerobic, hydrogen-oxidizing bacteria which require elemental sulfur, although all of the thermoacidophiles that grow optimally at temperatures higher than $65^{\circ} \mathrm{C}$ and at $\mathrm{pH}$ values less than $\mathrm{pH} 3.0$ described so far are archaea (15).

The fatty acid composition and quinone system of strain $3 \mathrm{H}-1^{\mathrm{T}}$ were identical to the fatty acid composition and quinone system of members of the genus of Hydrogenobacter, a genus of obligately chemolithoautotrophic, aerobic, hydrogen-oxidizing bacteria (11). The deduced $\mathrm{CO}_{2}$-fixing pathway of strain $3 \mathrm{H}-1^{\mathrm{T}}$ is a reductive tricarboxylic acid cycle similar to that of $H$. thermophilus (24) and " $H$. halophilus" (20). Major properties of the previously described obligately chemolithoautotrophic, aerobic, hydrogen-oxidizing bacteria and strain $3 \mathrm{H}-1^{\mathbf{T}}$ are shown in Table 2 . The taxonomic properties strongly support the hypothesis that strain $3 \mathrm{H}-1^{\mathrm{T}}$ belongs in the genus Hydrogenobacter.

However, significant differences between strain $3 \mathrm{H}-1^{\mathrm{T}}$ and the other Hydrogenobacter species were observed. Strain $3 \mathrm{H}-1^{\mathrm{T}}$ required elemental sulfur or thiosulfate for growth, whereas the other Hydrogenobacter species can grow by oxidizing hydrogen without sulfur or thiosulfate in the medium. The other Hydrogenobacter species can also utilize reduced sulfur compounds $(4,20)$, such as elemental sulfur and thiosulfate, as sole energy sources, although the growth of the other Hydrogenobacter species on reduced sulfur compounds is restricted to less aerobic conditions $\left(\mathrm{pO}_{2}\right.$, less than 0.05 atm [ $5.06 \mathrm{kPa}])$. In contrast, strain $3 \mathrm{H}-1^{\mathrm{T}}$ can grow on reduced sulfur compounds under aerobic conditions $\left(\mathrm{pO}_{2}\right.$, less than 0.20 atm $[20.3 \mathrm{kPa}]$ ).

Strain $3 \mathrm{H}-1^{\mathbf{T}}$ is motile by means of a polar flagellum, whereas the Hydrogenobacter strains studied previously are nonmotile.

The DNA G+C content of strain $3 \mathrm{H}-1^{\mathrm{T}}$ was $35.0 \mathrm{~mol} \%$, whereas the DNA G+C contents of other Hydrogenobacter strains and related strains are 38.6 to $46.0 \mathrm{~mol} \%(11,16,17$, 20). The DNA G+C content of strain $3 \mathrm{H}-1^{\mathrm{T}}$ was $8.7 \mathrm{~mol} \%$ lower than that of the type strain of $H$. thermophilus (strain TK-6). Furthermore, the lack of significant DNA-DNA homology between other Hydrogenobacter strains and strain $3 \mathrm{H}-1^{\mathrm{T}}$ showed that strain $3 \mathrm{H}-1^{\mathrm{T}}$ is genetically different from other Hydrogenobacter species.

Recently, the new genus Aquifex was proposed for a hyperthermophilic, hydrogen-oxidizing bacterium $(5,6)$. The

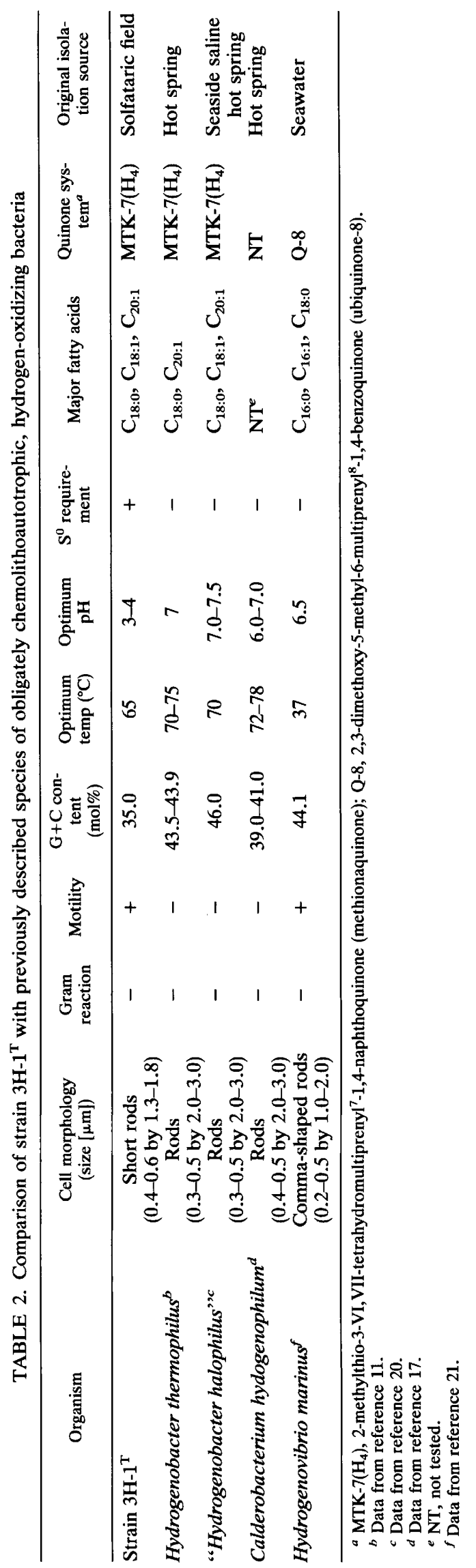


Aquifex strains are different from strain $3 \mathrm{H}-1^{\mathrm{T}}$ in their growth temperature and lipid profiles.

Two hydrogenases have been identified in hydrogenoxidizing bacteria; one is membrane bound and does not reduce NAD in vitro, and the other is a soluble, cytoplasmic, NAD-reducing enzyme. Most hydrogen-oxidizing bacteria, including members of the genus Hydrogenobacter, contain only the former hydrogenase $(8,23)$. Bonjour and Aragno described an exception, $B$. tusciae, a thermoacidophilic, facultatively chemolithoautotrophic, hydrogen-oxidizing bacterium which had only a soluble hydrogenase that did not reduce NAD (3). Strain $3 \mathrm{H}-1^{\mathrm{T}}$ contained both membranebound and soluble hydrogenases, and the soluble enzyme did not reduce NAD. Strain $3 \mathrm{H}-1^{\mathrm{T}}$ is also distinctive in its hydrogenase profile.

Although there are relatively large differences, strain $3 \mathrm{H}-1^{\mathrm{T}}$ shares several significant phenotypic characteristics with previously described Hydrogenobacter species. Thus, it is appropriate to treat strain $3 \mathrm{H}-1^{\mathrm{T}}$ as a member of a new species in the genus Hydrogenobacter.

Description of Hydrogenobacter acidophilus sp. nov. Hydrogenobacter acidophilus (a.ci.do'phi.lus. L. adj. acidus, sour; M.L. neut. n. acidum, acid; Gr. adj. philus, loving; M.L. adj. acidophilus, acid loving). Cells are short rods (0.4 to 0.6 by 1.3 to $1.8 \mu \mathrm{m}$ ) that occur singly or in linked chains containing two to four cells. Gram negative. Nonsporulating. Motile by means of a polar flagellum. Respiratory metabolism; molecular oxygen is used as the electron acceptor. Obligately chemolithoautotrophic, using hydrogen and reduced sulfur compounds as electron donors and carbon dioxide as a carbon source. Requires elemental sulfur or thiosulfate for growth. Hydrogenases are membrane bound and soluble. The soluble hydrogenases do not reduce pyridine nucleotides. Type $b, c$, and $o$ cytochromes are found. Carbon dioxide is fixed via the reductive tricarboxylic acid cycle. The optimum temperature for growth is $65^{\circ} \mathrm{C}$. The optimum $\mathrm{pH}$ for growth is 3 to 4 .

The $\mathrm{G}+\mathrm{C}$ content of the DNA is $35.0 \mathrm{~mol} \%$ (as determined by HPLC).

A straight-chain saturated $\mathrm{C}_{18: 0}$ acid and straight-chain unsaturated $C_{18: 1}$ and $C_{20: 1}$ acids are the major components of the cellular fatty acids.

2-Methylthio-3-VI,VII-tetrahydromultiprenyl ${ }^{7}$-1,4-naphthoquinone (methionaquinone) is the major component of the quinone system.

Isolated from mud samples from a solfatalic field in Tsumagoi, Japan. The type strain is strain $3 \mathrm{H}-1$ (= JCM 8795).

\section{ACKNOWLEDGMENTS}

We are grateful to Aiko Hirata (Institute of Applied Microbiology, University of Tokyo) and Naoya Ohmura (Central Research Institute of Electric Power Industry) for electron micrographs and for supplying isolation sources, respectively. We thank Yasuo Igarashi, Masaharu Ishii, and Tohru Kodama (University of Tokyo) for helpful discussions. We also thank Hirofumi Nishihara (University of Tokyo) for providing the cells used for the study of DNA-DNA homology and for helpful discussions. We acknowledge the technical assistance of Keiko Aoki (Bio Environment Research Corp.).

\section{REFERENCES}

1. Aragno, M. 1992. Aerobic, chemolithoautotrophic, thermophilic bacteria, p. 77-103. In J. K. Kristjansson (ed.), Thermophilic bacteria, CRC Press, Inc., Boca Raton, Fla.

2. Beatrice, M. C., and J. B. Chappell. 1979. The respiratory chain of Hydrogenomonas H-16. Biochem. J. 178:15-22.

3. Bonjour, F., and M. Aragno. 1984. Bacillus tusciae, a new species of thermoacidophilic, facultatively chemolithoautotrophic, hydrogen oxidizing sporeformer from a geothermal area. Arch. Microbiol. 139:397-401.

4. Bonjour, F., and M. Aragno. 1986. Growth of thermophilic, obligatorily chemolithoautotrophic hydrogen-oxidizing bacteria related to Hydrogenobacter with thiosulfate and elemental sulfur as electron and energy source. FEMS Microbiol. Lett. 35:11-15.

5. Burggraf, S., G. J. Olsen, K. O. Stetter, and C. R. Woese. 1992. A phylogenetic analysis of Aquifex pyrophilus. Syst. Appl. Microbiol. 15:352-356.

6. Huber, R., T. Wilharm, D. Huber, A. Trincone, S. Burggraf, H. König, R. Rachel, I. Rockinger, H. Fricke, and K. O. Stetter. 1992. Aquifex pyrophilus gen. nov., sp. nov., represents a novel group of marine hyperthermophilic hydrogen-oxidizing bacteria. Syst. Appl. Microbiol. 15:340-351.

7. Ishii, M., Y. Igarashi, and T. Kodama. 1989. Purification and characterization of ATP:citrate lyase from Hydrogenobacter thermophilus TK-6. J. Bacteriol. 171:1788-1792.

8. Ishii, M., S. Itoh, H. Kawasaki, Y. Igarashi, and T. Kodama. 1987. The membrane-bound hydrogenase reduces cytochrome $\mathrm{c}_{552}$ in Hydrogenobacter thermophilus strain TK-6. Agric. Biol. Chem. 51:1825-1831.

9. Ishii, M., T. Kawasumi, Y. Igarashi, and T. Kodama. 1987. 2-Methylthio-1,4-naphthoquinone, a unique sulfur-containing quinone from a thermophilic hydrogen-oxidizing bacterium, Hydrogenobacter thermophilus. J. Bacteriol. 169:2380-2384.

10. Kawasumi, T., Y. Igarashi, T. Kodama, and Y. Minoda. 1980. Isolation of strictly thermophilic and obligately autotrophic hydrogen bacteria. Agric. Biol. Chem. 44:1985-1986.

11. Kawasumi, T., Y. Igarashi, T. Kodama, and Y. Minoda. 1984. Hydrogenobacter thermophilus gen. nov., sp. nov., an extremely thermophilic, aerobic, hydrogen-oxidizing bacterium. Int. J. Syst. Bacteriol. 34:5-10.

12. Kitto, G. B. 1969. Intra- and extramitochondrial malate dehydrogenases from chicken and tuna heart. Methods Enzymol. 13:106-116.

13. Knüttel, K., K. Schneider, H. G. Schlegel, and A. Muller. 1989. The membrane-bound hydrogenase from Paracoccus denitrificans. Purification and molecular characterization. Eur. J. Biochem. 179:101-108.

14. Komagata, K., and K. Suzuki. 1987. Lipid and cell-wall analysis in bacterial systematics. Methods Microbiol. 19:161-207.

15. Kristjansson, J. K. 1992. Ecology of thermophilic eubacteria, p. 48. Program Abstr. Int. Conf. Thermophiles: Sci. Technol.

16. Kristjansson, J. K., A. Ingason, and G. A. Alfredsson. 1985. Isolation of thermophilic obligately autotrophic hydrogen-oxidizing bacteria, similar to Hydrogenobacter thermophilus, from Icelandic hot springs. Arch. Microbiol. 140:321-325.

17. Kryukov, V. R., N. D. Savelyeva, and M. A. Pusheva. 1983. Calderobacterium hydrogenophilum nov. gen., nov. sp., an extreme thermophilic hydrogen bacterium, and its hydrogenase activity. Mikrobiologiya 52:781-788.

18. Kurtenacker, A. 1938. Analytische Chemie der Sauerstoffsauren des Schwefels. Die chemische Analyse 38. Ferdinand Enke Verlag, Stuttgart, Germany.

19. Nishihara, H., Y. Igarashi, and T. Kodama. 1989. Isolation of an obligately chemolithoautotrophic, halophilic and aerobic hydrogen-oxidizing bacterium from marine environment. Arch. Microbiol. 152:39-43.

20. Nishihara, H., Y. Igarashi, and T. Kodama. 1990. A new isolate of Hydrogenobacter, an obligately chemolithoautotrophic, thermophilic, halophilic and aerobic hydrogen-oxidizing bacterium from seaside saline hot spring. Arch. Microbiol. 153:294-298.

21. Nishihara, H., Y. Igarashi, and T. Kodama. 1991. Hydrogenovibrio marinus gen. nov., sp. nov., a marine obligately chemolithoautotrophic hydrogen-oxidizing bacterium. Int. J. Syst. Bacteriol. 41:130-133.

22. Saito, H., and K. Miura. 1963. Preparation of transforming deoxyribonucleic acid by phenol treatment. Biochim. Biophys. Acta 72:619-629. 
23. Schlegel, H. G. 1989. Aerobic hydrogen-oxidizing (knallgas) bacteria, p. 305-329. In H. G. Schlegel and B. Bowien (ed.), Autotrophic bacteria. Science Tech Publishers, Madison, Wis.

24. Shiba, H., T. Kawasumi, Y. Igarashi, T. Kodama, and Y. Minoda. 1985. The $\mathrm{CO}_{2}$ assimilation via the reductive tricarboxylic acid cycle in an obligately autotrophic, aerobic hydrogenoxidizing bacterium, Hydrogenobacter thermophilus. Arch. Microbiol. 141:198-203.

25. Stetter, K. O. 1989. Extremely thermophilic chemolithoautotrophic archaebacteria, p. 167-176. In H. G. Schlegel and B. Bowien (ed.), Autotrophic bacteria. Science Tech Publishers, Madison, Wis.

26. Stetter, K. O., G. Fiala, G. Huber, R. Huber, and A. Segerer.
1990. Hyperthermophilic microorganisms. FEMS Microbiol. Rev. 75:117-124.

27. Storrie, B., and E. A. Madden. 1990. Isolation of subcellular organelles. Methods Enzymol. 182:203-225.

28. Suzuki, K., T. Kaneko, and K. Komagata. 1981. Deoxyribonucleic acid homologies among coryneform bacteria. Int. J. Syst. Bacteriol. 31:131-138.

29. Takeda, Y., F. Suzuki, and H. Inoue. 1969. ATP citrate lyase (citrate-cleavage enzyme). Methods Enzymol. 13:153-160.

30. Tamaoka, J., and K. Komagata. 1984. Determination of DNA base composition by reversed-phase high-performance liquid chromatography. FEMS Microbiol. Lett. 25:125-128. 